\title{
Mineralogical characteristics of pigments in paints and plasters from the Thracian tomb (3rd century BC) near the village of Dolno Lukovo, Southeast Bulgaria
}

\section{Минераложка характеристика на пигменти в бои и мазилки от тракийската гробница (III век пр. н. е.) до с. Долно Луково, Югоизточна България}

\author{
Eugenia Tarassova ${ }^{1}$, Mihail Tarassov ${ }^{1}$, Georgi Nekhrisov ${ }^{2}$ \\ Евгения Тарасова ${ }^{1}$, Михаил Тарасов ${ }^{1}$, Георги Нехризов ${ }^{2}$ \\ ${ }^{1}$ Institute of Mineralogy and Crystallography, Bulgarian Academy of Sciences, Bulgaria: E-mail: etarassova@mail.bg \\ ${ }^{2}$ National Archaeological Institute with Museum, Bulgarian Academy of Sciences, Bulgaria
}

Keywords: pigments, plasters, mineralogy, Thracian tomb, Bulgaria.

\section{Introduction}

The technologies used for laying plasters and coloring them in ancient tombs are a valuable source for our knowledge for the craftsmanship and way of life of Thracian society during the Early Hellenistic era. The Thracian tomb (3rd century BC) near the village of Dolno Lukovo, Ivailovgrad Municipality, Haskovo region (Fig. 1a) was discovered in 1991 after the treasure-hunter intervention (Nekhrizov, 1993). The tomb was seriously damaged by several interventions of the treasure-hunters in the 90s of the last century, and our information about the original decoration of this cult edifice comes mainly from the detailed description of Nekhrizov (2006). The tomb is built of local limestone and marble, has a gable roof and consists of an almost square funeral chamber, an antechamber, and a dromos. The decoration includes embossed ornaments (disk, squares, rectangles, star, horse head, and fish) in the first row of marble slabs of the chamber and plasters of different color. Initially, the chamber and antechamber were covered with white and colored plaster, of which now only a small part is preserved on place. The predominant colors are light-blue for the walls and white for the ceiling. The walls are decorated with belts painted in deep red, violet and dark-blue. The plasters in the antechamber are better preserved. From the floor up, the plaster includes a jutted out pale violet plinth, followed by imitation of blocks with ivory tints, then by a jutted out darkblue belt, and finally by a field of ochreous (light orange) plaster. The marble slabs on the floor of the chamber and antechamber are covered also by rose plaster. The goals of the present study are to establish the sequence of mortar application and to identify the materials used as pigments in paints and colored plasters from the tomb near the village of Dolno Lukovo.

\section{Material and methods}

Series of small samples of rose, light blue and orange colored plasters and red, violet and orange paints were studied in the Institute of Mineralogy and Crystallography, Bulgarian Academy of Sciences (Fig. 1, b, c, d, e). The sequences of application of mortars and paints were studied in polished specimens and thin sections using a binocular stereomicroscope (Carl Zeiss, Jena) and a light polarized microscope (Leitz-Orthoplan) equipped with an Olympus C-5060 digital camera. Chemical and phase composition of manually picked fragments of materials were studied using scanning electron microscopy (SEM) and electron probe microanalysis (EPMA) on a ZEISS SEM EVO 25LS equipped with an EDAX Trident system at $20 \mathrm{kV}$ acceleration voltage. All specimens for SEM and EPMA investigations were preliminary carbon coated to prevent the surface charging. EPMA study included energy dispersive spectroscopy (EDS) element analyses at selected points (point analyses) and selected areas (area analyses) using an EDAX SDD Apollo 10 EDS detector and Genesis V. 6.2. software with ZAF correction method. Since the analyzed grains were not polished, a standardless type of analysis was applied. For this purpose, the SEC (Standardless Element Coefficient) factors were updated for $20 \mathrm{kV}$ using the following standards: diopside (for $\mathbf{M g}, \mathbf{S i}, \mathrm{Ca}$ ), albite (Na, Al, Si), sanidine (K, Al, Si), apatite $(\mathbf{C a}, \mathbf{P})$, anhydrite $(\mathbf{C a}, \mathbf{S})$ and garnet $(\mathrm{Fe}$, $\mathrm{Mn}, \mathrm{Si}$ ). Since the predominant part of the studied samples was composed of calcium carbonate (calcite), the content of $\mathrm{CO}_{2}$ in them was determined by 
recalculation from the calcium content, and then the final analysis was normalized to $100 \%$.

\section{Results}

Plasters. The plasters in the tomb are two and three layered (Fig. 1, f, g, h, i, j). Each of them consists of lime binding material and filler. The first layer represents a coarse plaster (layer 1) which is followed by a fine white plaster (layer 2). The fine white plaster (layer 2) is covered by a colored fine plaster (layer 3 ) which is either rose, or light-orange, or light-blue.

Coarse plaster (layer 1). The content of $\mathrm{CaCO}_{3}$ in the used binder is $94-97 \mathrm{wt}^{\%} \%$. The low and variable contents (3-6 wt \%) of other components such as $\mathrm{SiO}_{2}, \mathrm{Al}_{2} \mathrm{O}_{3}, \mathrm{MgO}, \mathrm{Fe}_{2} \mathrm{O}_{3}, \mathrm{Na}_{2} \mathrm{O}, \mathrm{SO}_{3}$ are related to the low and variable contents of clay minerals in the limestone used for the preparation of lime. The filler takes up 60-65 vol\% of the plaster and is a sandy material with a grain size $<2 \mathrm{~mm}$. Aggregates of quartz, epidote-chlorite and quartz-albite-sericite as well as individual minerals such as potassium feldspar (with perthite of replacement), acid plagioclase, quartz, biotite, muscovite, chlorite, pyroxene, magnetite, amphibole, olivine, replaced by serpentine, botryoidal goethite and others were established in the filler. The grains of minerals have angular shape which indicates their restricted mechanical transport. The identified minerals are typical for gneisses, gneiss-schists and basalts widespread in the region (Kozhoukharov et al., 1991).

Fine white plaster (layer 2) is with thickness of 2-3.5 mm. The content of $\mathrm{CaCO}_{3}$ in the used binder is $97.4-99.2 \mathrm{wt} \% \mathrm{CaCO}_{3}$. Other established com- ponents are $\mathrm{SiO}_{2}, \mathrm{Al}_{2} \mathrm{O}_{3}, \mathrm{MgO}, \mathrm{Fe}_{2} \mathrm{O}_{3}$ and $\mathrm{SO}_{3}$. The filler takes up 60-65 vol\% of the plaster and consist mainly of calcite (with content of $\mathrm{MgO}$ to $0.8 \mathrm{wt} \%$ ), and small quantities of dolomite and quartz aggregates. The grains of the binder have a size $<1 \mathrm{~mm}$.

Fine rose, light-orange, and light-blue plasters (layers 3) are with thickness to $1-1.5 \mathrm{~mm}$. Phase and chemical composition of the binder and filler and their relative volumes are the same as those in the fine white plaster. The rose coloration of the plaster is achieved by adding a ground mixture of hematite, undefined brown clay material and plumbojarosite, containing $\mathrm{CuO}$ to $1 \mathrm{wt} \%$, to the lime mortar. For the light-orange coloration of the plaster, a ground mixture of goethite, plumbojarosite, clay material and hematite is used. Charcoal ground to particle with a size of $0.003-0.15 \mathrm{~mm}$ is used as coloring pigment for the light-blue plaster, where the color depth depends on the amount of pigment.

Paints. Paint palette used in the decoration includes three colors: red, violet and orange. The paints are applied in thin layers of about $0.1 \mathrm{~mm}$. The phase and chemical compositions of the paints allow us to conclude that the technology of preparation of the paints was the same and involved mixing a slaked lime solution, mineral filler (calcite and muscovite - to a lesser extent, with a grain size of $0.03-0.1 \mathrm{~mm}$ ) and pigments. All paints were applied on fresh wet plaster (fresco technique) (Piovesan et al., 2012) which is evidenced by pigment particles penetrated into the underlying layer (layer 3). Calcite used as filler contains $\mathrm{MgO}$ to $0.8 \mathrm{wt} \%$.

Red paint is applied on the fine rose plaster (layer 3 , rose) (Fig. 1f, j). Hematite, plumbojarosite, clay
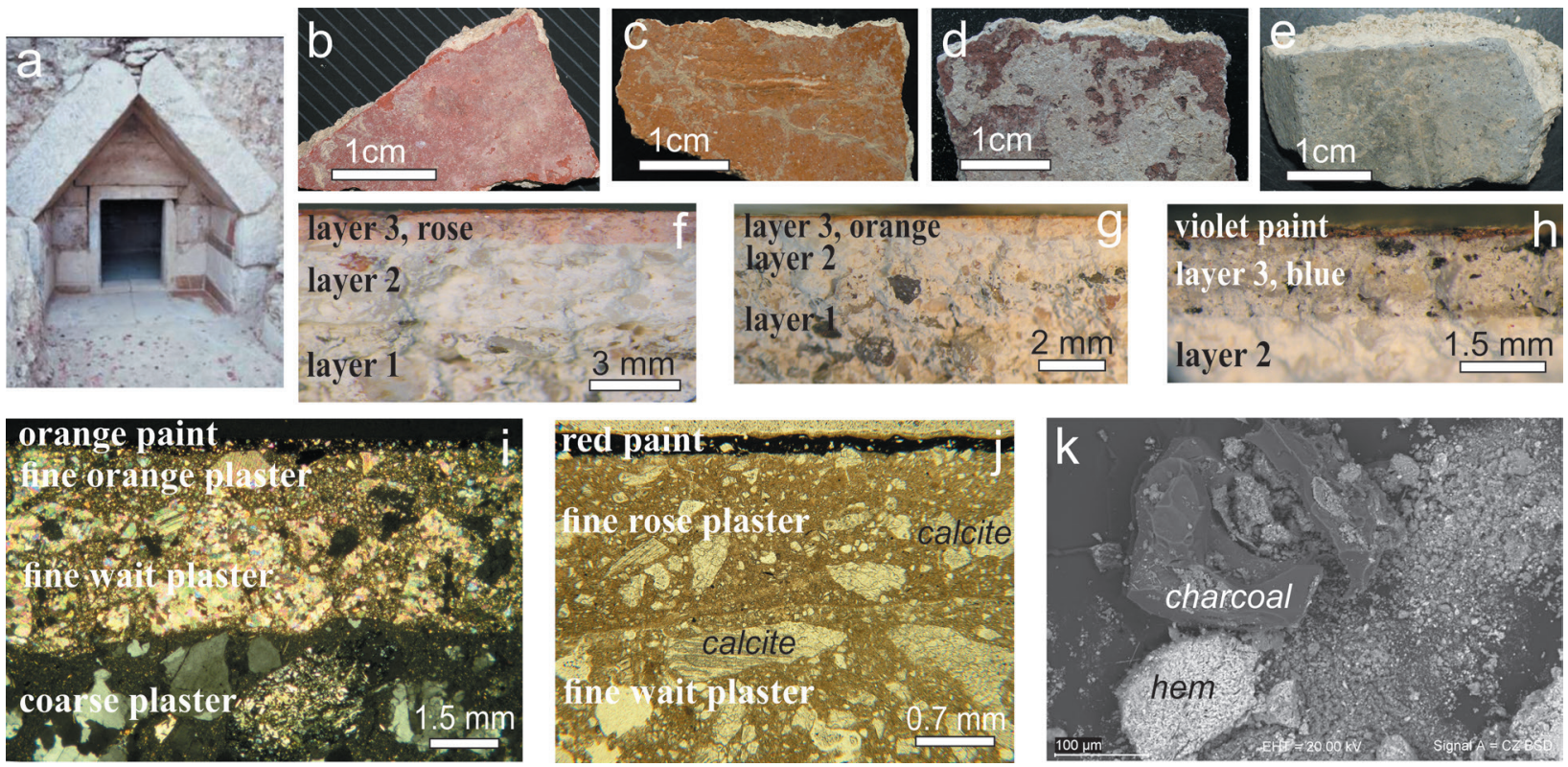

Fig. 1. $a$, Thracian tomb near the village of Dolno Lukovo; $b, c, d$ and $e$, studied fragments of color decoration: $b$, red paint, $c$, orange paint, $d$, violet paint, $e$, fine light-blue colored plaster; $f, g$ and $h$ cross-sections of three layered plasters (stereomicroscope image): $f$, with red paint, $\mathrm{g}$, with orange paint, $\mathrm{h}$, with violet paint; $i$, and $j$, cross-sections of the plasters (transmitted light, planepolarized light): $I$, cross-sections of plaster layers 1 and 2 and orange paint; $j$-cross-sections of plaster layers 2 and 3 and red paint; $k$, charcoal (burnt wood) with hematite from violet paint (BSE image, SEM) 
material and goethite are used as coloring pigments in the paint. In the paint we found a grain of native gold with $\mathrm{Cu}$ content of $2.2 \mathrm{wt} \%$. The presence of copper was established also in plumbojarosite and goethite (to $1.1 \mathrm{wt} \%$ of $\mathrm{CuO}$ ), and hematite (to $0.8 \mathrm{wt} \%$ of $\mathrm{CuO}$ ). Hematite contains also As (to $2.7 \mathrm{wt} \%$ of $\mathrm{As}_{2} \mathrm{O}_{3}$ ). Observations of the paint under an optical microscope reveal that it is inhomogeneous and in some places there are yellow spots where goethite predominates. The filler takes up about $5-8 \%$ of the paint and is represented by crashed calcite and single flakes of muscovite.

Orange paint is applied on the fine orange plaster (Fig. 1g). Orange color is achieved by mixing of yellow and red pigments. The following coloring minerals (pigments) are established in the paint: botryoidal goethite $(0.96 \mathrm{wt} \%$ of $\mathrm{PbO})$, hematite, plumbojarosite, siderite with galena, clay material, microradial fibrous goethite. Plumbojarosite has constant minor elements such as $\mathrm{Cu}$ and $\mathrm{Zn}$ (to $1.42 \mathrm{wt} \%$ of $\mathrm{CuO}$ and to $1.65 \mathrm{wt} \%$ of $\mathrm{ZnO}$ ). Calcite crystals are used as filler (to 25-30\%) and to achieve a glossy paint effect.

Violet paint is applied on the fine light-blue plaster (Fig. 1h). The coloring in violet is achieved by mixing red pigments and ground charcoals. Hematite with inclusions of magnetite, goethite (with $\mathrm{CuO}$ to $0.7 \mathrm{wt} \%$ ) and clay material were found in the paint. Similarly to the red paint, the filler takes up about $5-8 \%$ of the paint and is represented by crashed calcite and single flakes of muscovite.

\section{Discussion and conclusion}

The found, albeit small, difference in the chemical composition of the binder in the coarse (layer 1) and fine (layers 2 and 3) plasters indicates a difference in the raw materials (limestones) used for the production of lime. The mortar used for plastering layer 1 is stronger than that used for layer 2, since the content of the so-called "hydraulic components" $\left(\mathrm{SiO}_{2}, \mathrm{Al}_{2} \mathrm{O}_{3}, \mathrm{Fe}_{2} \mathrm{O}_{3}\right)$ in the binder of the first material is higher (to $6 \mathrm{wt} \%$ ). More essential differences between the two plasters can be seen in the filler used. For the coarse plaster, sandy materials originated from gneisses, gneiss-schists, schists and basic rocks from the region (Kozhoukharov et al., 1991), were used, while for the fine plaster crashed calcite (marble) was used. Pigments used for paints and colored plasters are the same - they are natural earth pigments (hematite, goethite, plumbojarosite, clay material) and one artificial but easy available pigment - charcoal. All color nuances (rose, orange, violate) and color depth are achieved by mixing pigments. Paints (mixtures of slaked lime solution, mineral filler as calcite, and pigments) are applied on wet freshly plastered fine plaster by fresco technique. Calcite and rarely muscovite crystals in the paint are used as filler and to achieve a glossy paint effect. The identified pigments and the presence in them of such minor elements as $\mathrm{Zn}, \mathrm{Cu}, \mathrm{Pb}$ and $\mathrm{As}$, as well as the found natural $\mathrm{Au}$ are unambigu- ous indications for the provenance of the pigments, from the oxidation zones of $\mathrm{Pb}-\mathrm{Zn}$ deposits in the Eastern Rodopes. The most likely source of the pigments is the well-developed oxidation zone of the Madzharovo Au-Pb-Zn deposit (Breskovska, Gergelchev, 1988).

The decoration of the Thracian tomb near the village of Dolno Lukovo demonstrates the traditional for this time techniques of preparation and application of the mortars and paints (Nekhrizov et al., 2017). Charcoal - a cheap and easily accessible artificial pigment for light- to dark-blue coloring was widely used in other Thracian tombs from the Early Hellenistic era, such as the Shushmanets tomb (Tarassova et al., 2014) and the Documaci tomb (Tarassova et al., 2019).

Acknowledgement: The research is funded by the General academic project of Bulgarian Academy of Sciences "Thracians - genesis and development of ethnicity, cultural identity, civilizational interactions and heritage of antiquity", 2017.

\section{References}

Breskovska, V., V. Gergelchev. 1988. Madzharovo ore field. - In: Lead-zinc Deposits in Bulgaria. Sofia, Technica Publishing House, 114-126 (in Bulgarian).

Kozhoukharov, D., I. Boyanov, A. Goranov, E. Kozhoukharova. 1991. Geological Map of Bulgaria in Scale M 1:100 000. Ivaylovgrad Map Sheet. Sofia, "Geology and Geophysics" AD.

Nekhrizov, G. 1993. Thracian tomb in Dolno Lukovo. - Rodopi, 5, 10-12 (in Bulgarian).

Nekhrizov, G. 2006. The tomb near Dolno Lukovo - architecture and decoration. - In: Discussion Workshop "Another Point of View". Monumental tombs and funeral buildings in Thracia - documents, interpretations, socialization. Gyulechitsa, December 2006, 18 p. (in Bulgarian); https:// www.academia.edu/2648867/

Nekhrizov, G., G. Avdeev, E. Tarassova, M. Tarassov, R. Titorenkova, N. Petrova, B. Stamboliyska, M. Rogozherov, D. Yancheva, R. Kukeva, P. Markov, D. Nihtianova, Ts. Dimitrov, R. Stoyanova. 2017. Comparative analysis of pigments, pigmented plasters and building materials used in the construction of Thracian cult edifices. Thracian antiquity: technological and genetic research, history and intangible heritage. - In: Collection of Research Papers in Honor of 75th Anniversary of Petar Mandzhukov. Sofia, Bulgarian Academy of Sciences, 84-100 (in Bulgarian).

Piovesan, R., C. Mazzoli, L. Maritan, P. Cornale. 2012. Fresco and lime-paint: an experimental study and objective criteria for distinguishing between these painting techniques. - Archaeometry, 54, 4, 723-736.

Tarassova, E., M. Tarassov, A. Pavlov. 2014. Phase and chemical composition of ancient pigments used in decoration of the Thracian tomb-temple Shushmanets, Shipka town, Bulgaria. - In: Proceedings of the National Conference "Geoscience 2014", Sofia, Bulgarian Geological Society, 121-122.

Tarassova E., M. Tarassov, R. Titorenkova. 2019. Ancient pigments from the Early Hellenistic Documaci Tomb (4-3rd $\mathrm{BC})$, near the Town of Mangalia, Romania: mineralogical and chemical characteristics. -Rev. Bulg. Geol. Soc. 80, 3, 256-258. 